\title{
ANALYZING THE USES OF EVENT MARKETING STRATEGY AS THE EXPERIENTIAL MARKETING STRATEGY OF BANK: A STUDY ON A COMMERCIAL BANK LIMITED
}

\author{
Asraful Islam \\ Master of Business Administration \\ Department of Marketing \\ Faculty of Business Studies \\ Bangabandhu Sheikh Mujibur Rahman Science and Technology University \\ Gopalganj-8100, Bangladesh \\ E-mail: sisir.dew7007@gmail.com \\ Abdullah Al Mamun \\ Master of Business Administration \\ Department of Marketing \\ Faculty of Business Studies \\ Bangabandhu Sheikh Mujibur Rahman Science and Technology University \\ Gopalganj-8100, Bangladesh \\ E-mail: abdullahalmamun394@gmail.com \\ Mijanur Rahman Molla \\ Master of Business Administration \\ Department of Marketing \\ Faculty of Business Studies \\ Bangabandhu Sheikh Mujibur Rahman Science and Technology University \\ Gopalganj-8100, Bangladesh \\ E-mail:mijanmkt53@gmail.com
}

Received: November 29, $2021 \quad$ Accepted: December 20, $2021 \quad$ Online Published: February 1, 2022

DOI: $10.46281 /$ ijmri.v6i1.1581

URL: https://doi.org/10.46281/ijmri.v6i1.1581

\begin{abstract}
The study investigates is to analyze the uses of event marketing of a bank: A study on a commercial bank. To identify the uses of event marketing as experiential marketing in the banking sector is present in Bangladesh. It is clear that event marketing makes the bank more profitable than other advertising strategies because it can grasp client attention than other marketing strategies. Event marketing can increase loans more than other advertising strategies. Event marketing strategy is that given greater control over clients because it can grasp clients' minds with memorable experiences or promotional events. The findings of this study suggest that most government bank doesn't pay more attention to event marketing. But private banks pay more attention to event
\end{abstract}


marketing and experiential marketing and they are beneficial with this. So it can be that a combination of event marketing and experiential marketing is the best solution for any bank for chooses their marketing tools. In commercial bank limited they need to increase event marketing because the uses of events become increasing day by day. An event marketing strategy that has a big opportunity in Bangladesh. There is no potential risk of using event marketing in the bank.

Keywords: Bank, Marketing Mix, Strategy.

\section{JEL Classification Codes: M30.}

\section{INTRODUCTION}

Event marketing is a strategy marketers use to endorse their brand, products, or service with an inperson or real-time engagement. These events can be online or offline and companies can contribute as hosts, participants or sponsors, marketers use both inbound and outbound event marketing strategies for promotional purpose. In the $20^{\text {th }}$ century, communication and connectivity with customers are important for business. Bank or companies need conscious to make their communication that hasn't done past. They have more difficulty which makes this work highly sophisticated. For communicating with customers, organizations can use event marketing as the experiential marketing. We know that event marketing is working with the strategy where the company invited people physically or virtually and makes conversation or does some activities with them. After those activities, they said about the product or offer to the customer. At present, we can use event marketing offline also online. Another side experiential marketing means to experience something before the product. For better experiential marketing, the company needs to organize many events. So we can tell that even marketing and experiential marketing work together for the organization. That's why we can use event marketing as the experiential marketing for the bank. It will be helpful for the bank because when they organize it, customers will be known about their service and bank. Also, customers can be experience their service freely. If they like those experiences which they use, they will be opened more accounts to the bank.

At present, event marketing as the experiential marketing is a general policy used in the promotion of goods and brand. Bankers are all the time searching for an efficient path to sort away and alluring their clientele. They use this event and experiential marketing to attract their customers. Many people of the country don't know about foreign exchange, loans, interest even how to open an account in a bank. This is a big problem for the bank. They can invite the customer to a specific event to experience their service.

The method of marketing is to promote their services to the market by memorable experience or promotional things. Here involve the promotion in a low budget full of an unconventional and surprising way of advertising which allows high levels of innovation. Event marketing have evolved and developed with the enlargement mankind (Daniel, 2012) Thus event may be component of the economic or social or cultural, business environment, part of the tertiary sector. Event can be described as non-standard services in which the awareness, behavior and commitment to such service provider are crucial (Daniel, 2012). The project paper is more important for bankers to know the significance of the uses of event marketing as the experiential marketing. At present, antagonism is high in the market. So, if any bank wants to position on the customer's mind then they have to follow some unique strategy in a bank. As Bangladesh is developing towards economic growth (Akhter et al., 2020a; Akhter et al., 2020b; Jahan et al., 2020; Asheq et al., 2021; Kumar et al., 2019; Al Amin et al., 2020; Akhter et al., 2021; Tu et al., 2021; Ara et al., 2015; Ali et al., 2021; Ali et al., 2020; Baqir et al., 2020; Batool et al., 2021; Islam \& 
Bhuiyan, 2021; Islam \& Barghouthi, 2017; Islam et al., 2014; Islam \& Miajee, 2018; Islam, 2016a; Islam, 2016b; Islam, 2016c; Islam et al., 2015; Hossain et al., 2017; Islam, 2015; Islam \& Barghouthi, 2017; Islam et al., 2021; Sharif \& Karim, 2017; Karim et al., 2021), it is necessary to study event marketing of commercial banks.

\section{LITERATURE REVIEW}

The premise of this study based around the research of Daniel (2012). He did his research on the uses of event marketing management strategies and further research possibility (Daniel, 2012). His study was event marketing concept and other possibility where he was defining event marketing and event management. A marketing strategy is a declaration in regard to how a certain brand or product researches it's goals, giving a understandable way for the market segment, target market identification, positioning, element of the market mix, and the market mix cost (Morgan et al., 2019). A marketing strategy is focus on allocating and creating market resources to achieve the goals (Cespedes \& Piercy, 1996). Therefore, the scope of marketing strategy is on how to define the market in a product line or certain product (Greenley, 1989). Then, the company will find its own competitive qualities and integrate them into the element of the marketing mix which is in line with the demand and needs of a potential customer in a market target (Constantinides, 2006). The researcher will analyze the uses of event marketing as the experiential marketing strategy as a new marketing strategy in bank and identify the uses of event marketing as the experiential marketing strategy as a new marketing strategy in bank. And also provide some recommendations or guidelines for bankers to use event marketing as the experiential marketing strategy as a new marketing strategy in bank. Defining event marketing can be based on its chronological context as the thought kept on changing opening from the initial time it was exposed and up until now (Wood, 2009). Nonetheless, the most up-to-date description that can be consequent is that everything that is measured innovative and interesting is below event marketing (Wohlfeil \& Whelan, 2006). Event promoting is that the united effort of actions taken to encourage an event. Effective marketing creates a obligation for your event during detection and creating and a fulfilling client wants (Gupta, 2003).

\section{METHODOLOGY}

The objective of research suggests that the paper is both exploratory and descriptive. An exploratory study is one that uses interviews to gather data, whereas a more structured study is one that uses a questionnaire.

Table 1. Gender status of respondents

\section{RESULTS \& DISCUSSION}

\begin{tabular}{|c|c|c|}
\hline Name & Frequency & Percent \\
\hline Male & $\mathbf{6 9}$ & $\mathbf{6 9 . 0 0}$ \\
\hline Female & $\mathbf{3 1}$ & $\mathbf{3 1 . 0 0}$ \\
\hline Total & $\mathbf{1 0 0}$ & $\mathbf{1 0 0 . 0}$ \\
\hline
\end{tabular}

Table at the above shows that $69.00 \%(n=69)$ of the respondents are male and the rest $31.00 \%$ $(n=31)$ of the respondents are female. 
Table 2. Frequency of executives and employee of using event marketing as the experiential marketing make bank profitable (source survey)

Using event marketing as the experiential marketing is profitable for your bank.

\begin{tabular}{|l|l|l|}
\hline & Frequency & Percent \\
\hline Strongly Agree & $\mathbf{7 5}$ & $\mathbf{7 5 . 0}$ \\
\hline Agree & 25 & $\mathbf{2 5 . 0}$ \\
\hline Neutral & $\mathbf{0}$ & $\mathbf{0}$ \\
\hline Disagree & 0 & 0 \\
\hline Strongly Disagree & 0 & 0 \\
\hline Total & 100 & 100.0 \\
\hline
\end{tabular}

This table on top of shows that $75.0 \%(n=75)$ of the respondents strongly agreed to facilitate using marketing as the experiential marketing makes the bank more profitable than other advertising strategies because it can grasp client attention than other marketing strategies. By the information of this table, this is the evidence that using event marketing as the experiential marketing make bank profitable.

Table 3. Frequency of executives and employee of event marketing as the experiential marketing can increase loans

\begin{tabular}{|l|l|l|}
\hline & Frequency & Percent \\
\hline Strongly Agree & $\mathbf{7 1}$ & $\mathbf{7 1 . 0}$ \\
\hline Agree & 29 & $\mathbf{2 9 . 0}$ \\
\hline Neutral & 0 & $\mathbf{0}$ \\
\hline Disagree & 0 & 0 \\
\hline Strongly Disagree & 0 & 0 \\
\hline Total & 100 & 100.0 \\
\hline
\end{tabular}

This table on top of shows to facilitate $71.0 \%(\mathrm{n}=71)$ of the respondents strongly agreed and besides $29.0 \%(n=29)$ of the respondents agreed that using event marketing as the experiential marketing can increase loans than other advertising strategy because it can grasp client attention than other marketing strategy. By the information of this table, this is the evidence that event marketing as the experiential marketing can increase loans.

Table 4. Frequency of executives and employee of event marketing as the experiential marketing is beneficial.

\begin{tabular}{|l|l|l|}
\hline & Frequency & Percent \\
\hline Strong Agree & $\mathbf{8 2}$ & $\mathbf{8 2 . 0}$ \\
\hline Agree & 17 & $\mathbf{1 7 . 0}$ \\
\hline Neutral & 1 & $\mathbf{1 . 0}$ \\
\hline Disagree & $\mathbf{2 0}$ & $\mathbf{0}$ \\
\hline Strongly Disagree & 0 & $\mathbf{0}$ \\
\hline Total & 100 & 100.0 \\
\hline
\end{tabular}


This chart on top of shows that $82.0 \%(n=82)$ of the answer strongly agreed and also $17.0 \%$ $(n=17)$ of the answer agreed that using event marketing as the experiential marketing is beneficial than other advertising strategy. By the information of this table, this is the evidence that event marketing as the experiential marketing is beneficial.

Table 5. Frequency of executives and employee of event marketing as the experiential marketing gives us greater control over clients

\begin{tabular}{|l|l|l|}
\hline & Frequency & Percent \\
\hline Strongly Agree & $\mathbf{5 4}$ & $\mathbf{5 4 . 0}$ \\
\hline Agree & 29 & $\mathbf{2 9 . 0}$ \\
\hline Neutral & 14 & $\mathbf{1 4 . 0}$ \\
\hline Disagree & $\mathbf{3}$ & $\mathbf{3 . 0}$ \\
\hline Strongly Disagree & 0 & $\mathbf{0}$ \\
\hline Total & 100 & $\mathbf{1 0 0 . 0}$ \\
\hline
\end{tabular}

This table above shows that $54.0 \%(\mathrm{n}=54)$ of the respondents strongly agreed and also $29.0 \%(n=29)$ of the respondents agreed that using event marketing as the experiential is given greater control over clients. By the information of this table, this is the evidence that event marketing as the experiential marketing is given greater control over clients.

Table 6. Frequency of executives and employee of event marketing as the experiential marketing is more convenient than other strategy

\begin{tabular}{|l|l|l|}
\hline & Frequency & Percent \\
\hline Strongly Agree & $\mathbf{6 9}$ & $\mathbf{6 9 . 0}$ \\
\hline Agree & $\mathbf{3 0}$ & $\mathbf{3 0 . 0}$ \\
\hline Neutral & $\mathbf{1}$ & $\mathbf{1 . 0}$ \\
\hline Disagree & 0 & $\mathbf{0}$ \\
\hline Strongly Disagree & 0 & $\mathbf{0}$ \\
\hline Total & $\mathbf{1 0 0}$ & $\mathbf{1 0 0 . 0}$ \\
\hline
\end{tabular}

This chart above shows to facilitate $69.0 \%(n=69)$ of the answer strongly agreed and also $30.0 \%(n=30)$ of the answer agreed that using event marketing as the experiential is more convenient than other strategy. By the information of this table, this is the evidence that event marketing as the experiential marketing is more convenient than other strategy.

Table 7. Frequency of executives and employee of there is a big opportunity to event marketing as the experiential marketing in bangladesh

\begin{tabular}{|l|l|l|}
\hline & Frequency & Percent \\
\hline Strongly Agree & $\mathbf{7 4}$ & $\mathbf{7 4 . 0}$ \\
\hline Agree & 23 & $\mathbf{2 3 . 0}$ \\
\hline Neutral & $\mathbf{3}$ & $\mathbf{3 . 0}$ \\
\hline Disagree & $\mathbf{0}$ & $\mathbf{0}$ \\
\hline Strongly Disagree & 0 & $\mathbf{0}$ \\
\hline Total & $\mathbf{1 0 0}$ & $\mathbf{1 0 0 . 0}$ \\
\hline
\end{tabular}


This table on top of shows to facilitate $74.0 \%(n=74)$ of the respondents strongly agreed and as well $23.0 \%(n=23)$ that of the respondents agreed using event marketing as the experiential is a big opportunity in Bangladesh. By the information of this table, this is the evidence that event marketing as the experiential marketing is a big opportunity in Bangladesh.

Table 8. Frequency of executives and employee event marketing as the experiential marketing is easy to use on business

\begin{tabular}{|l|l|l|}
\hline & Frequency & Percent \\
\hline Strongly Agree & $\mathbf{5 5}$ & $\mathbf{5 3 . 4}$ \\
\hline Agree & 29 & $\mathbf{3 3 . 4}$ \\
\hline Neutral & 14 & $\mathbf{1 0 . 9}$ \\
\hline Disagree & 2 & $\mathbf{2 . 3}$ \\
\hline Strongly Disagree & 0 & $\mathbf{0}$ \\
\hline Total & 100 & $\mathbf{1 0 0 . 0}$ \\
\hline
\end{tabular}

This chart above shows to facilitate $55.0 \%(\mathrm{n}=55)$ of the respondents strongly agreed and as well $29.9 \%(n=29)$ of the respondents agreed that using event marketing as the experiential is easy on bank because in that way bank employee do not face any difficult problem and also finished within very low cost. By the information of this table, this is the evidence that event marketing as the experiential marketing is easy to use on bank.

Table 9. Frequency of executives and employee of event marketing as the experiential marketing helps to make more profit than others

\begin{tabular}{|l|l|l|}
\hline & Frequency & Percent \\
\hline Strongly Agree & $\mathbf{5 8}$ & $\mathbf{5 8 . 0}$ \\
\hline Agree & 31 & $\mathbf{3 1 . 0}$ \\
\hline Neutral & $\mathbf{5}$ & $\mathbf{5 . 0}$ \\
\hline Disagree & $\mathbf{4}$ & $\mathbf{4 . 0}$ \\
\hline Strongly Disagree & 2 & $\mathbf{2 . 0}$ \\
\hline Total & 100 & $\mathbf{1 0 0 . 0}$ \\
\hline
\end{tabular}

This chart on top of shows to facilitate $58.0 \%(\mathrm{n}=58)$ of the respondents strongly agreed and as well $31.0 \%(n=31)$ of the respondents agreed that event marketing as the experiential marketing helps to make more profit than others. By the information of this table, this is the evidence that event marketing as the experiential marketing helps to make more profit than others.

After the face to face interview with the customer in Dhaka city, the researcher got the following information from them:

Maximum clients didn't know about event marketing. There are very few people who knew about event marketing. Only the students of the university and some of the people who work in various companies or banks were known to event marketing. Some people said that they knew about event marketing as the experiential marketing after we described which activities are event marketing involved. Most of the clients said that they didn't know about event marketing but when we give an example of some event marketing at that time they realized it. People who knew about event marketing as the experiential marketing, most of them are students and marketers who knew 
about event marketing from the very beginning. So in short, it can be said that very few people know about event marketing as the experiential marketing. And after discussing event marketing, they said that they see this type of marketing. Maximum customers face that sort of marketing strategy but they didn't know about it. But when we talked about and described the event marketing they understood the matter. Clients said that they faced event marketing and by facing these types of marketing strategy they were influenced by it but still they didn't know that it was a event marketing. Maximum clients didn't understand the event marketing as the experiential marketing strategy but after we talked about it with them, they realized about the event marketing as the experiential marketing they faced and the influence they got by it.

Most of the clients who said that they faced event marketing made clear to me that they saw event marketing in the local area and besides the road or sometimes in an unexpected location. Someone said that they saw on Facebook. Most of the clients said that they saw the event marketing as the experiential marketing strategy in mass located area Almost $60 \%$ of clients said that they saw event marketing as the experiential marketing in a crowded area, university and some people mentioned that they saw event marketing strategy in Chattagram tourist area. Mostly event marketing as the experiential marketing has seen in the crowded of Dhaka city. Most of the customers, who are said that they faced event marketing as the experiential marketing, cleared to me that they saw it in the crowded areas when they buy goods but mostly not in the banking sector. Over all $60 \%$ customers said that they experienced event marketing as the experiential marketing strategy but mostly in the private banking sector. The rest $40 \%$ of customers said that they have not seen that in the banking sector and also some people said that they have no experience with the but mostly not in the banking sector marketing strategy. Clients said that they share their experience with their friends and relative when they face these types of strategy. People who faced event marketing strategy, most said that they shared this type of experience with their relatives and some people also said that they shared it with their friends. Almost all of the people who face event marketing as the experiential marketing said that event marketing was memorable and most of the time it was interesting to them, that's why they shared it with their relatives and friends. Few people who face or event marketing, said that event marketing as the experiential marketing sometimes was disturbing to them in crowded areas.

Who face event marketing as the experiential marketing in private bank, said that it was interesting. Most of the clients who face event marketing thought that marketing is always interesting for the cause of surprising and memorable strategy of event marketing. Almost $50 \%$ of clients, who faced event marketing as the experiential marketing, said that event marketing is interesting. But $10 \%$ of clients, who faced event marketing, said that event marketing as is disturbing for grasping their attention because few banks didn't think about client's sentiment. The rest $10 \%$ of customers are neutral about event marketing because they said that sometimes event marketing as the experiential marketing is interesting and sometimes not. People who face event marketing as in the banks said that they never forgot it because it was surprising and memorable. Most of the customers who faced event marketing said that for the cause of surprising and memorable content that was not forgettable for them, they could not forget about those services. Like VIP dinner or posted video in social media that what was occur last year event. Most of the clients said that if they face the same thing again and again then they understand it. Most of the clients said that it is easy to find event marketing because they face more and more this marketing strategy and that is always memorable and surprising to them. One respondent said that event marketing that is found out to be outside the box, means that it is not the traditional concept of adverting that attracts them a lot. That's why most of the clients said that event marketing is easy 
to find out because that is not in the traditional form of advertising or way to retain clients and it is always exceptional than other marketing strategies. They can also find out from email marketing.

\section{CONCLUSION}

According to the finding, it can be said that event marketing that makes the bank more profitable than other advertising strategies because it can works with directly clients. The user and the respondents want to use event marketing that make more memorable than others. Most people are now use facebook, if they see something surprising then that will easily attract them. In this situation charming event attract the client most. From the study, it can also be said that event marketing strategy that has a big opportunity in Bangladesh. Also event marketing is an important promotional tool for a bank. So the uses of event marketing in the bank have potential and some banks already used this strategy because it can easily attract clients.

Conceptualization: Asraful Islam

\section{AUTHOR CONTRIBUTIONS}

Formal Analysis: Asraful Islam, Abdullah-Al-Mamun, Mijanur Rahman Molla

Funding Acquisition: Asraful Islam, Abdullah-Al-Mamun, Mijanur Rahman Molla

Investigation: Asraful Islam, Abdullah-Al-Mamun, Mijanur Rahman Molla

Methodology: Asraful Islam

Project Administration: Asraful Islam, Abdullah-Al-Mamun, Mijanur Rahman Molla

Resources: Asraful Islam, Abdullah-Al-Mamun, Mijanur Rahman Molla

Software: Asraful Islam

Supervision: Asraful Islam, Abdullah-Al-Mamun, Mijanur Rahman Molla

Validation: Asraful Islam, Abdullah-Al-Mamun, Mijanur Rahman Molla

Visualization: Asraful Islam, Abdullah-Al-Mamun, Mijanur Rahman Molla

Writing - Original Draft: Asraful Islam,

Writing - Review \& Editing: Asraful Islam, Abdullah-Al-Mamun, Mijanur Rahman Molla

\section{CONFLICT OF INTEREST STATEMENT}

The authors declare that they have no competing interests.

\section{ACKNOWLEDGEMENT}

All authors contributed equally to the conception and design of the study.

\section{REFERENCES}

Al Amin, M., Arefin, M. S., Sultana, N., Islam, M. R., Jahan, I., \& Akhter, A. (2020). Evaluating the customers' dining attitudes, e-satisfaction and continuance intention toward mobile food ordering apps (MFOAs): evidence from Bangladesh. European Journal of Management and Business Economics, 30(2), 211-229. https://doi.org/10.1108/EJMBE04-2020-0066

Akhter, A., Hossain, M. U., \& Asheq, A. A. (2020a). Influential factors of social entrepreneurial intention in Bangladesh. The Journal of Asian Finance, Economics, and Business, 7(8), 645-651. 
Akhter, A., Asheq, A. A., Hossain, M. U., \& Karim, M. K. (2020b). Exploring customer intentions to adopt mobile banking services: Evidence from a developing country. Banks and Bank Systems, 15(2), 105-116.

Akhter, A., Karim, M. M. \& Islam, K. M. A. (2021). The impact of emotional intelligence, employee empowerment and cultural intelligence on commercial bank employees' job satisfaction. Banks and Bank Systems, 16(4), 11-21.

Ara, E., Akhter, A., \& Hoque, M. A. (2015). Analyzing the Changes of Preference Factors of Billboard by the Gender, Age \& Occupation of Customer: A Study on Dhaka City. AIUB Journal of Business and Economics, 12(1), 81-100.

Asheq, A. A., Tanchi, K., Kamruzzaman, M., \& Karim, M. M. (2021). The impact of e-marketing orientation, technological orientation and learning capacity on online SME performance. Innovative Marketing, 17(3), 168-179.

Ali, M. C., Islam, K. A., Chung, S. J., Zayed, N. M., \& Islam, K. M. A. (2021). The Correlation Between Job-Hopping Attitude And Turnover Behavior: A Job Satisfaction Perspective In Bangladesh. International Journal of Business and Management Future, 5(1), 14-26.

Ali, M. C., Islam, K. M. A., Chung, S. J., Zayed, N. M., \& Afrin, M. (2020). A Study of Green Human Resources Management (GHRM) and Green Creativity for Human Resources Professionals. International Journal of Business and Management Future, 4(2), 57-67.

Baqir, M., Hussain, S., Waseem, R., \& Islam, K. M. A., (2020). Impact of Reward and Recognition, Supervisor Support on Employee Engagement. American International Journal of Business and Management Studies, 2(3), 8-21.

Batool, N., Hussain, S., Baqir, M., Islam, K. M. A., \& Hanif, M. (2021). Role of HR Technology And Training For The Development Of Employees. International Journal of Business and Management Future, 5(1), 1-13.

Constantinides, E. (2006). The marketing mix revisited: towards the 21 st century marketing. Journal of marketing management, 22(3-4), 407-438.

Cespedes, F. V., \& Piercy, N. F. (1996). Implementing marketing strategy. Journal of Marketing Management, 12(1-3), 135-160.

Daniel, M. (2012). The uses of event marketing management strategies. Procedia - Social and Behavioral Sciences, 5409-5413.

Gupta, S. (2003). Event marketing: Issues and challenges. IIMB Management Review, 15(2), 8796.

Greenley, G. E. (1989). An understanding of marketing strategy. European Journal of marketing, 23(8), 45-58. 
Islam, K. M. A., \& Bhuiyan, A. B. (2021). Determinants of the effectiveness of internal Shariah audit: Evidence from Islamic banks in Bangladesh. The Journal of Asian Finance, Economics, and Business, 8(2), 223-230.

Islam, K. M. A., \& Barghouthi, O. A. (2017). Risk Management of Islamic Banking: An Islamic Perspective. International Journal of Islamic Banking and Finance Research, 1(1), 25-28.

Islam, K. M. A., \& Miajee, M. R. K. (2018). Small and Medium Enterprises (SMEs) Financing in Bangladesh: A Review of Literature. International Journal of Small and Medium Enterprises, 1(1), 11-15.

Islam, K. M. A. (2016a). Financial Performance Comparison of Top Rated Banking Financial Institutions (BFIs) of Bangladesh. Indian Journal of Science, 23(85), 669-697.

Islam, K. M. A. (2016b). Factors influencing consumers purchase decision: a case study of Pantene shampoo. Indian Journal of Science, 23(88), 910-923.

Islam, K. M. A. (2016c). Corporate Governance: Conjecture and Modernism. Indian Journal of Science, 23(86), 798-817.

Islam, K. M. A., Alam, I., \& Al-Amin, D. M. (2015). Foreign exchange operation of private commercial banks in Bangladesh: A case study on AB Bank Limited. International Journal of Innovative Research and Creative Technology, 1(3). 296-304.

Hossain, S. A., Islam, M. N., Mahmud, M. S., \& Islam, K. M. A. (2017). Evaluation of Financial Performance of Commercial Banks in Bangladesh: Comparative Study Based on CAMEL Approach. The Millennium University Journal, 2(1), 54-77.

Hossain, M. U. (2021). Relationship between Individual Characteristics and Social Entrepreneurial Intention: Evidence from Bangladesh. Business and Economics Research Journal, 12(2), 385-397.

Hossain, M. U., Arefin, M. S., \& Yukongdi, V. (2021). Personality Traits, Social Self-Efficacy, Social Support, and Social Entrepreneurial Intention: The Moderating Role of Gender. Journal of Social Entrepreneurship, 1-21.

Islam, K. M. A. (2015). Throughput accounting: a case study. International Journal of Finance and Banking Research, 1(2), 19-23.

Islam, K. M. A., Alam, I., \& Hossain, S. A. (2014). Examination of profitability between Islamic banks and conventional banks in Bangladesh: A comparative study. Research in Business and Management, 1(1), 78-89.

Islam, K. M. A., \& Barghouthi, O. A. (2017). Risk Management of Islamic Banking: An Islamic Perspective. International Journal of Islamic Banking and Finance Research, 1(1), 25-28. 
Islam, K. M. A., Sadekin, M. S., Rahman, M., Chowdhury, M., \& Haque, A. (2021). The impact of Shariah supervisory board and Shariah audit committee on CSR adoption at Islamic banks. Journal of Asian Finance, Economics and Business (JAFEB), 8(3), 479-485.

Jahan, N., Ali, M. J., \& Al Asheq, A. (2020). Examining the key determinants of customer satisfaction Internet banking services in Bangladesh. Academy of Strategic Management Journal, 19(1), 1-6.

Karim, M. M., Bhuiyan, M. Y. A., Nath, S. K. D., \& Latif, W. B. (2021). Conceptual Framework of Recruitment and Selection Process. International Journal of Business and Social Research, 11(02), 18-25.

Kumar, B., Asheq, A. A., Rahaman, M., \& Karim, M. M. (2019). Determinants of Social Media Marketing Adoption among SMEs: A Conceptual Framework. Academy of Marketing Studies Journal, 23(3), 1-6.

Morgan, N. A., Whitler, K. A., Feng, H., \& Chari, S. (2019). Research in marketing strategy. Journal of the Academy of Marketing Science, 47(1), 4-29.

Sharif, A. M., \& Karim, M. (2017). Influence of job analysis program on employees: a study on selected companies of Bangladesh. International Journal of Scientific and Engineering Research, 8(5), 1221-1225.

Tu, B., Bhowmik, R., Hasan, M., Asheq, A. A., Rahaman, M., \& Chen, X. (2021). Graduate Students' Behavioral Intention of toward Social Entrepreneurship: Role of Social Vision, Innovativeness, Social Proactiveness, and Risk Taking. Sustainability, 13(11), 6386.

Wohlfeil, M., \& Whelan, S. (2006). Consumer motivations to participate in event-marketing strategies. Journal of Marketing Management, 22(5-6), 643-669.

Wood, E. H. (2009). Evaluating event marketing: experience or outcome?. Journal of Promotion Management, 15(1-2), 247-268.

\section{Copyrights}

Copyright for this article is retained by the author(s), with first publication rights granted to the journal. This is an open-access article distributed under the terms and conditions of the Creative Commons Attribution license (https://creativecommons.org/licenses/by/4.0). 